\title{
STUDENTE SE PERSEPSIES OOR DIE MOONTLIKE OORDRAG VAN AKADEMIESE GELETTERHEIDSVAARDIGHEDE NA ANDER LEERKONTEKSTE
}

\author{
Karlien Cillié \\ Marisca Coetzee \\ Universiteit Stellenbosch
}

Die eksplisiete onderrig van kennis-en vaardigheidsoordrag speel 'n integrale rol in beide die kritieke en spesifieke uitkomste van hoër onderwys juis omdat hierdie tipe aanleg die vermoë om te dink, te redeneer, te beplan en ooreenkomstige besluite op 'n strategiese wyse te neem, onderlê. Vir menige studente geskied die vaardigheid van oordrag nie outomaties nie aangesien die toepassing daarvan gesofistikeerde nadenke oor die abstrahering van die korrekte patroon/formule/beginsels vanuit een situasie vir toepassing op 'n gelyksoortige of totaal andersoortige situasie impliseer. Om onder andere hierdie rede dui navorsing oor die afgelope nege dekades (1920-2012) daarop dat onderriginstellings klaaglik daarin misluk om enige wesenlike oordrag by leerders en studente te bewerkstellig. Vervolgens word daar deur hierdie artikel gepoog om 'n bydrae te lewer tot die sentrale rol wat kennis- en vaardigheidsoordrag in institusionele beplanning rondom die kurrikulumaanbod van eerstejaarstudente speel. Die moontlikheid word ondersoek of 'n akademiesegeletterdheidsintervensie binne die eerstejaarskurrikulum ingespan kan word om die oordrag van kritiese denkvaardighede na ander leermodules te bewerkstellig, terwyl dit tergelyktydig aan die voorwaardes van suksesvolle oordrag, soos gë̈dentifiseer deur Perkins en Salomon (1992), voldoen: deeglike en diverse oefening, eksplisiete abstrahering, aktiewe selfmonitering, die gebruik van metafore en/of analogië̈ en die stimulering van opmerksaamheid. Nadat elke voorwaarde vir optimale oordrag aan die hand van kursusinhoud bespreek en kwalitatiewe data rakende die kursus geïllustreer word, word die afleiding gemaak dat sodanige intervensies nuttig en volhoubaar kan wees om studente te ondersteun deur hulle met die nodige leesstrategieë en -vaardighede vir ander leerkontekste toe te rus.

Explicit instruction in the transfer of knowledge and skills plays an integral role in both the critical and specific outcomes of higher education. The reasoning is that this type of ability instils a capacity to think, reason, plan and to make corresponding decisions in a strategic manner. For many students, the transfer of certain skills is not automatic because their application is dependent on extensive consideration of the correct pattern/formula/principles. These may be applied in one situation but require a deliberate search for connections with other contexts. Research over the past nine decades (1920-2012) indicates that teaching institutions have mostly failed in their attempt to teach their students any effective means of transfer. The aim of this article is to contribute to the central role that the transfer of knowledge and skills plays in the institutional planning of the curriculum offered to first-year students. In it, the possibility of using an academic literacy intervention, within the first year 
curriculum, to enable the transfer of critical thinking skills to other learning modules is investigated. The conditions for successful transfer, by means of systematic practice, explicit conceptualisation, active self-monitoring, the use of metaphors and/or analogies and the role of mindfulness, as identified by Perkins and Salomon (1992), are also examined. Each condition for optimal transfer is then discussed on the basis of course content, supported by the relevant qualitative data. In the article, a conclusion is reached that such interventions could be used to equip students with the necessary reading strategies and skills to cope successfully in other learning contexts.

\section{INLEIDING}

Kennis- en vaardigheidsoordrag vorm die grondslag vir leer, denke en probleemoplossing omdat dit onderliggend is aan die vermoë om te dink, te redeneer, en te beplan en om besluite op 'n strategiese wyse te neem. Ten spyte van die belang van oordrag dui navorsing oor die afgelope nege dekades (1920-2012) daarop dat onderriginstellings daarin misluk om enige wesenlike oordrag by leerders en studente te bewerkstellig (Haskell, 2001; Chi \& VanLehn, 2012). Alhoewel die omgewing van kennis- en vaardigheidsoordrag somber geskets word, beleef navorsing op hierdie gebied oor die afgelope 20 tot 25 jaar 'n oplewing en bly dit ' $n$ onderwerp wat sentraal staan, veral as dit kom by institusionele beplanning rakende die kurrikulumaanbod van eerstejaarstudente (Barrie, 2006; Billing, 2007;Salomon, 1987 \& 1989; Detterman, 1993; De Corte, 1999; Fallon, Lahar \& Susman, 2009; James, 2010; Marini \& Genereux, 1995; Perkins \& Salomon, 1988).

\section{PROBLEEMSTELLING EN DOEL}

Die uitdagende aard van oordragsonderrig lê in sy kontrasterende karakter: daar word van die leerder verwag om 'n vaardigheid in 'n spesifieke konteks aan te leer, maar terselfdertyd bestaan die verwagting ook dat dié bekwaamheid suksesvol op ander kontekste toegepas moet word. Dit is juis om hierdie rede dat heelwat dosente en onderwysers mismoedig voor die situasie staan: die leerder of student kon die bepaalde klasoefening baasraak, maar binne 'n ander konteks slaag hy of sy nie daarin om hierdie vaardighede met sukses toe te pas nie (Billing, 2007; Perkins \& Salomon, 1992; Resnick, 1987; Yager, 1991). In die meeste gevalle, was die leerder of student ook nie eens daarvan bewus dat hy of sy oor bestaande kennis vir die situasie beskik nie.

Die doel van hierdie artikel is om verslag te doen oor hoe studente die moontlike oordrag van akademiese geletterdheidsvaardighede na ander leerkontekste ervaar het en om te bepaal of sodanige ondersteuningsinisiatiewe ingespan kan word om die oordrag van spesifiek kritiese denkvaardighede te kan bewerkstellig. Die premie wat hedendaags (21ste eeu) op die onderrig van kritiese denkvaardighede geplaas word (Barnett, 2004; Bessick, 2008; Bowden, Hart, King, Trigwell \& Watts, 2000; Stupnisky, Renaud, Daniels, Haynes \& Perry, 2008) is so hoog dat dit saam met die verwerwing van kommunikatiewe bekwaamhede, interpersoonlike vaardighede en rekenaargeletterdheid eweneens as 'the basic compencies or skills that every graduate [should] have' gereken word (Diamond, 1997; Hadiyanto, 2010; Rugarcia, Felder, Woods \& Stice, 2000).

Vervolgens fokus hierdie artikel op een so 'n kritiese denkvaardigheidsintervensie van eerstejaarstudente wat as illustrasie dien dat studente wel daarvan bewus gemaak kan word 
hoe om vaardighede vanuit een konteks na 'n ooreenstemmende en soms selfs andersoortige konteks te kan oordra. Ten eerste word die oordragsmodel van Salomon en Perkins (1987) beskryf en bespreek. Daar is op hierdie model besluit omdat dit die eerste in sy soort was waarin die vennootskap tussen algemene kennis en gespesialiseerde kennis binne 'n opvoedkundige konteks voorgestel is. Die model onderskei tussen drie vlakke waarop die oordrag van kennis en vaardighede in die onderwyskonteks plaasvind, naamlik die oordrag van basiese vaardighede, die oordrag van kennis en die oordrag van (kritiese) denkvaardighede. Soos reeds genoem, is dit veral op die laasgenoemde vlak wat die klem van hierdie artikel sal val. Benewens die model, ondersoek die artikel by wyse van 'n akademiese geletterdheidsintervensie die optimale omstandighede wat volgens Perkins en Salomon (1992) bydra tot die moontlikheid van suksesvolle oordrag (deeglike en diverse oefening, eksplisiete abstrahering, aktiewe selfmonitering, gebruik van metafore en/of analogieë en die aanmoediging van opmerksaamheid) aangesien vaardigheidsoordrag nie per se plaasvind nie. Die beskrywing en bespreking van data vir die bepaling van suksesvolle vaardigheidsoordrag al dan nie, wat versamel is uit studente response op 'n elektroniese vraelys, vorm die volgende onderwerp van bespreking. Die artikel sluit af met enkele, dog voorlopige, gevolgtrekkings oor die sukses van die oordrag van akademiese denkvaardighede.

\section{METODOLOGIE}

Die Universiteit Stellenbosch (US) is reeds die afgelope paar jaar besig om vanuit institusionele vlak taalondersteunings- en akademiese geletterdheidsmodules in die voorgraadse kurrikulum in te bou. Sulke modules berus sterk op die veronderstelling dat vaardighede wat binne een konteks aangeleer word oordraagbaar is na ander relevante en nuwe kontekste. Die US se Fakulteit Natuurwetenskappe bied sedert 2007 die verpligte module Wetenskapskommunikasievaardigheid 172 (WKV 172) aan. Hierdie kwalitatiewe studie fokus op die 2009-groep.

Die hoofuitgangspunt wat daar in die onderrigbenadering van hierdie module gevolg is, en die waarde hiervan, word soos volg deur Ramsden (1988:271) saamgevat:

[1]earning should be seen as a qualitative change in a person's way of seeing, experiencing, understanding and conceptualizing something in the real world - rather than as a quantitative change in the amount of knowledge someone possesses.

Hierdie stelling van Ramsden beklemtoon die waarde van die kwaliteit wat in die leerproses plaasgevind het en wat ook deur die navorsers van die studie insgelyks as die beste getuigskrif vir oordrag beskou kan word. As gevolg hiervan is daar ondermeer besluit om studente se ervaring deur middel van 'n elektroniese vraelys in te win. Deur die respondente se reaksies op die oop vrae in die vraelys te analiseer, kon etlike afleidings oor die waarde van die akademiese geletterdheidsintervensie ten op sigte van die oordrag van leervaardighede gemaak word. Om gevolglik te bepaal of vaardigheidsoordrag van WKV 172 na ander leerkontekste plaasgevind het, word daar in hierdie studie uitsluitlik op kwalitatiewe data gefokus. Die kwantitatiewe data is egter nie buite rekening gelaat nie en het deel gevorm van 'n ander studie deur Van Dyk, Cillié, Coetzee, Ross, en Zybrands (2011). 


\section{DIE OORDRAGSMODEL}

Ten einde te bepaal of daar 'n oordrag van akademiese taalvaardighede van $W K V 172$ na ander leerkontekste plaasgevind het, is daar op die oordragsmodel van Perkins en Salomon (1987) en Salomon en Perkins (1989) besluit, wat bevindinge rakende vaardigheidsoordrag gesintetiseer het deur die erkenning van twee afsonderlike, maar tog verwante, oordragsmodelle, te wete die hoofpad- ('low road') model en die grondpad- ('high road') model. Waar die hoofpadmodel verwys na die ontwikkeling van kennis of 'n vaardigheid tot 'n hoë vlak van outomatisasie (soos motorbestuur of boeklees), juis omdat die vaardigheid onbewustelik in 'n soortgelyke konteks toegepas kan word, verwys die grondpadmodel na die doelbewuste onttrekking van 'n idee uit 'n bepaalde konteks en die doelbewuste abstrahering en toepassing daarvan op 'n totaal andersoortige konteks, deur gesofistikeerde nadenke. Die bestuurder let op die hobbels en sanderige gedeeltes van hierdie metaforiese pad en daar heers 'n bewussyn dat hierdie pad strategies benader moet word (Taaldiens, 2012). Die inlees en afleiding van inligting (die hartklop van die grondpadmodel) om die patroonmatigheid daarvan binne ' $n$ spesifieke teks te bepaal is ook die fokus van die ander eerstejaarsvakke binne die Fakulteit Natuurwetenskappe (Fisika, Rekenaarwetenskap, Rekenaarvaardigheid, Waarskynlikheidsleer en Wiskunde), waar daar van studente verwag word om juis hierdie vaardighede te kan toepas om uiteindelik 'n bepaalde formule te kan ontsyfer. Terselfdertyd moet studente, soos in die geval van WKV 172, kan verduidelik waarom iets die antwoord is en nie noodwendig wat die antwoord is nie. Vir baie studente is hierdie proses intellektueel uitdagend omdat hulle nuwe inligting binne hul bestaande denkraamwerk moet konstrueer ten einde iets betekenisvols te kan leer (Hanley, 1994).

Vir die doeleindes van hierdie studie is daar op die hoofpad-oordragsmodel besluit. Die redes hiervoor is tweërlei. Eerstens is dit moontlik dat lees- en leervaardighede as konkrete denkprosesse wel onderrig kan word en derhalwe kan studente daartoe in staat gestel word om die strategieë verbonde aan hierdie vaardighede ook in hul ander vakke toe te pas. Die wyse waarop lees- en leervaardighede in WKV 172 onderrig word, word later in die artikel onder die optimale omstandighede vir vaardigheidsoordrag bespreek. Tweedens, het die tydbeperking waaraan die kursus onderhewig was ook 'n invloed op die modelkeuse gehad. WKV 172 word slegs twee maal per week aangebied. Dit is belangrik om in gedagte te hou dat studente heelwat méér oefening in kritiese denkvaardighede benodig as wat fakulteite weens hul eie vol eerstejaarroosters vir hierdie doel kan afstaan. Benewens akademiese taalvaardigheidskursusse benodig studente verdere ontwikkeling en verfyning van leesvaardighede vir akademiese sukses. Indien $W K V 172$ as voorbeeld van 'n intervensie waarin onderrig van kennis- en vaardigheidsoordrag plaasvind bewys kan word, bestaan daar meer gronde om fakulteite te motiveer, eerstens, om sodanige kursusse in te stel en, tweedens, om dit uit te brei en te verleng, om uiteindelik studente se kans op akademiese sukses te verbeter.

\section{DIE AKADEMIESE GELETTERDHEIDSINTERVENSIE WETENSKAPSKOMMUNI- KASIEVAARDIGHEID 172}

Wetenskapskommunikasievaardigheid 172 (WKV 172) is 'n akademiese geletterdheidsintervensie wat die US se Fakulteit Natuurwetenskappe in 2007 in die eerstejaarskurrikulum geïmplementeer het in 'n poging om die krisis rakende deurvloeikoerse 
en lae vlakke van taalvaardigheid aan te spreek. Die kursus is hoofsaaklik daarop gemik om eerstejaarstudente se akademiese lees-, skryf- en denkvaardighede só te ontwikkel dat oordrag van hierdie vaardighede moontlik na hulle ander modules kan plaasvind. Om hierdie belangrike rede, rus die onus op dosente om studente in die vaardigheid te onderrig om dít wat in 'n vorige en bekende konteks geleer is in 'n nuwe onbekende konteks te kan herken en gevolglik te kan oordra.

Akademies lees en akademies skryf word deurlopend geïntegreerd in die agtkrediet-jaarkursus van twee periodes per week aangebied en word nie as afsonderlike eenhede óf as verwyderd van kritiese denkvaardighede gesien nie. Die vermoë om akademiese diskoers te beheers word hedendaags vaardigheidsneutraal gedefinieer aangesien 'n fokus op vaardighede per se beperkend van aard is: die een vaardigheid voorveronderstel altyd integrasie met van die ander (Van Dyk et al., 2011).Vaardighede behoort dus nie in isolasie beskou te word nie en die oorblywende deel van hierdie artikel moet binne hierdie konteks gelees word.Vervolgens word die raamwerk van die leesmodule en die onderrig van lees- en leervaardighede bespreek.

\section{KURSUSRAAMWERK}

Begripslees- en kritiesleestegnieke is as interaktiewe denk- en leerprosesse in die leesmodule onderrig en is deurlopend gekonkretiseer deur refleksiewe vrae oor die leesproses (soos 'Wat beteken lees vir jou?', 'Watter leserskema word op 'n spesifieke teks toegepas?' en 'Hoe monitor ek my begrip van die teks tydens die leesproses?'), toepassing op verskillende soorte tekste, asook in die vorm van klasgesprekke. Studente is nie slegs onderrig in die wyse waarop hulle moet lees nie, maar hulle moes ook deurlopend en op 'n krities-evaluerende wyse dink waarom hulle op 'n spesifieke manier lees.

Ten einde die belang daarvan te beklemtoon dat leesvaardighede buigbaar is en op enige leesen leerkonteks van toepassing is, is studente ook deurlopend bewus gemaak van hoe hulle begripslees- en kritiesleesstrategieë na ander inhoudsverwante vakke soos Biologie, Fisiologie en Sielkunde kon oordra. Afgesien van inhoud wat met WKV 172 oorvleuel, is hierdie ook lees- en aldus leerintensiewe modules.

Die oordrag van leesvaardighede na vakke van 'n andersoortige (numeriese) aard is egter nie geïgnoreer nie. Alhoewel ander eerstejaarsmodules soos Fisika, Rekenaarwetenskap, Rekenaarvaardigheid, Waarskynlikheidsleer en Wiskunde nie inhoudelik met WKV 172 ooreenstem nie, is dit wel moontlik om die kritiese leesvaardigheid van analise, interpretasie, afleiding en evaluering daarna te herlei. In hierdie syfermatige vakke gaan dit oorwegend oor die inlees en afleiding van inligting en die gepaardgaande patroon ten einde uiteindelik 'n formule te kan ontsyfer. Terselfdertyd moet studente kan verduidelik hoekom iets die antwoord is en nie noodwendig net wat die antwoord is nie.

\section{DIE OPTIMALE OMSTANDIGHEDE VIR VAARDIGHEIDSOORDRAG}

Verskeie studies (Billing, 2007; Day \& Goldstone, 2012; Perkins \& Salomon, 2012) toon dat oordrag suksesvol kan plaasvind wanneer die leersituasie reg is. Om hierdie rede moet die ideale en optimale omstandighede waarbinne vaardigheidsoordrag kan plaasvind in oënskou geneem word. Perkins en Salomon (1992) het uiteindelik vyf omstandighede geïdentifiseer waarbinne suksesvolle oordrag sal kan plaasvind, naamlik, (1) deeglike en diverse oefening, 
(2) eksplisiete abstrahering, (3) aktiewe selfmonitering, (4) die gebruik van metafore en/of analogieë en (5) die aanmoediging van opmerksaamheid. Vervolgens word die skep van hierdie omstandighede binne die $W K V$-module ondersoek en veral hoe dit bygedra het tot vaardigheidsoordrag.

\section{1) Deeglike en diverse oefening}

Nadat Perkins en Salomon (1992) die bevindinge van enkele oordragsverwante studies (Luria, 1976; Scribner \& Cole, 1981) met mekaar vergelyk het, het hulle tot die gevolgtrekking gekom dat 'transfer may depend on extensive practice of the performance in question in a variety of contexts.' (Perkins \& Salomon, 1992: 1)

WKV 172 is so ontwerp dat bykans geen klaskontaksessies die vorm van 'n lesing aanneem nie. Daar word van studente verwag om, deur middel van selfontdekking, hetsy individueel of in groepverband, probleemgesentreerd te werk te gaan. So, byvoorbeeld, sal nuwe konsepte by wyse van 'n teks geïllustreer word eers nadat studente probleme kritiesdenkend moes oplos. Studente se antwoorde word deur die fasiliteerder geëvalueer of studente word aangemoedig om die probleem weer in oënskou te neem of vanuit ' $n$ ander invalshoek te benader. Die fasiliteerder verskaf dus slegs die nodige stimuli, maar nie die antwoord nie. Nadat die beginsel dan in die klas gedemonstreer en bespreek is, sal studente verskeie geleenthede kry waarbinne die (nuwe) vaardigheid geoefen en vasgelê kan word. Ten einde deeglike inoefening te bewerkstellig word studente herhaaldelik daarop gewys dat dieselfde beginsels steeds toegepas moet word namate nuwe leerinhoude in moeilikheidsgraad opbou.

Nog 'n belangrike metode waarby deeglike en diverse oefening, maar veral ook die vereiste van opmerksaamheid (wat later bespreek word) in die klas bevorder is, is dat studente gereeld gevra word om na te dink oor wat hulle tydens 'n betrokke les geleer het en wat van toepassing elders in hul studies kan wees. Op hierdie manier bly studente deurentyd waaksaam binne die lessituasie en op soek na maniere om dit waarmee hulle kennis maak in 'n akademiese geletterdheidsintervensie in BSc-verwante modules te kan toepas. So vind daar dus nie net deeglike inoefening van 'n bepaalde vaardigheid plaas nie, maar dit vind ook binne diverse omgewings plaas.

\section{2) Eksplisiete abstrahering}

Een van die uitkomste van die $W K V$ 172-module is die identifisering van argumentstrukture en die uiteindelike herkenning en analise daarvan in outentieke akademiese tekste. As vertrekpunt word 'n vereenvoudigde teks met 'n bykans 'perfekte' argumentstruktuur ter illustrasie gebruik, waarin studente, onder meer, die gevolgtrekking, hoofstelling en neweskikkende stellings met voorbeelde moet kan identifiseer. Sodra studente die beginsels van die argumentstruktuur begryp, word daar van hulle verwag om dieselfde beginsels op meer 'n komplekse teks toe te pas. Studente wat die eerste teks met gemak eksplisiet kon abstraheer is meer suksesvol in hierdie opvolgaktiwiteite, wat strook met die bevindinge van studies soos onderneem deur Gick en Holyoak (1980; 1983) en James (2010). Die sukses van studente se vermoë om beginsels eksplisiet te abstraheer hang natuurlik ook nou saam met deeglike en diverse inoefening.

\section{3) Aktiewe selfmonitering}


Alhoewel die hoofpadmodel die oorwegende oordragsmodel was, is die grondpadmodel ook in die kursus gebed deur die klem te plaas op veral metakognitiewe refleksie op denkprosesse, een van die optimale omstandighede wat daar vir suksesvolle oordrag geskep moet word (Salomon \& Perkins, 1992) en wat deur Belmont, Butterfield en Ferretti (1982) suksesvol bewys is. Binne die module is studente deurgaans aangemoedig om aktief te leer deur probleme deur kritiese nadenke op te los, instede daarvan om aangebode feite bloot passief in te neem. Metakognitiewe refleksie is een van die moeilikste prosesse vir eerstejaarstudente om te bemeester en dié onvermoë om hul denkprosesse eksplisiet te verbaliseer is 'n taak wat deurlopend in die $W K V$ 172-module aangespreek word. 'n Rasionele, kritiese probleemopossingsbenadering is deurgaans aangemoedig. Studente is gereeld bewus gemaak dat hul response getuig van kulturele en waardeskemata wat die logika vertroebel. Daarom is hulle aangemoedig om objektief te reageer.

\section{4) Die gebruik van metafore en/of analogieë}

Volgens die model van Perkins en Salomon (1992) word oordrag heelwat beter gefasiliteer wanneer nuwe onbekende materiaal of vaardighede as 'n relevante analogie of metafoor binne 'n student se bestaande korpus van kennis en vaardighede aangeleer kan word. Latere navorsing deur Glynn, Yeany en Britton (1991) en Glynn en Takahashi (1998) oor die gebruik van analogieë in wetenskapsonderrig ondersteun hierdie oogpunt. Meer onlangse studies van Carter en Pitcher (2010) en Nagel, Blignaut en Cronjé (2011) moedig onderwysers en dosente aan om metafore bewustelik as pedagogiese hulpmiddels in hul onderrigbenadering te integreer, juis omdat dit so suksesvol is.

Metafore en analogieë werk volgens die beginsel dat die persoon se bestaande kennis oor die bekende korpus van kennis oorgedra word na die 'nuwe' en onbekende domein, en op dié wyse 'n beter begrip van die onbekende kan vorm. Een so 'n voorbeeld is waar studente vir die eerste keer kennis maak met die struktuurelemente van 'n akademiese teks. Dit word byvoorbeeld vergelyk met 'n fisiese struktuur van 'n huis waar enige huis oor basiese struktuurelemente moet beskik. Net so word studente dan gevra om die strukturele komponente van 'n teks te identifiseer. Indien enige struktuurelemente ontbreek, word studente gevra om na te dink oor die effek van so 'n swakplek in 'n huis se struktuur. Hierdie gebreke of tekortkominge word dan getransponeer na die effek daarvan op 'n akademiese teks.

\section{5) Die aanmoediging van opmerksaamheid}

Die laaste toestand vir optimale vaardigheidsoordrag blyk, onses insiens, die belangrikste te wees aangesien dit ook die regte klimaat vir eksplisiete abstrahering en aktiewe selfmonitering skep. Salomon en Globerson (1987) verwys na hierdie vorm van metakognitiewe refleksie as doelbewuste opmerksaamheid van die student wat 'n integrerende rol in oordrag speel. Langer (1989) beskryf opmerksaamheid as 'n algemene toestand van waaksaamheid of wakkerheid ten opsigte van die aktiwiteite waarmee die persoon besig is én die (leer)omgewing waarin die persoon hom of haar bevind. Dit staan dan ook in skrille kontras tot enige vorm van passiewe leer. Opmerksaamheid veronderstel dus betrokkenheid deur die student, wat ook direk met die kritieke uitkomste van WKV 172 korrespondeer, naamlik, om die student met behulp van relevante akademiese taal/denkstrategieë taalmatig én kognitief te bemagtig om 'n strategiese denker te word wat op 
kritiese (besinnende) wyse met klasmaats, dosente en hom- of haarself kan kommunikeer oor gelese en geskrewe tekste waarin probleme geïdentifiseer en opgelos word en inligting versamel, geanaliseer, georden en geëvalueer word. Die konstruksie van betekenis berus op die onderhandeling tussen die studente onderling asook tussen studente en dosente. Kennis word dus nie net van dosente na studente oorgedra nie.

\section{DATA}

Die data vir die bepaling van suksesvolle vaardigheidsoordrag, al dan nie, is versamel uit reaksies op 'n elektroniese vraelys wat via die US se e-leerbestuurstelsel Webstudies aan die 2009 klas beskikbaar gestel is. Respondente het vrywilliglik aan die ondersoek deelgeneem. Hulle was ten volle ingelig oor die aard, doel en disseminasie van die navorsing, terwyl hul anonimiteit deurgaans gewaarborg is. Die vraelyste is in die lig van die US se algemene beleid vir etiese klaring vir navorsing hanteer.

Die vrae is direk afgelei uit die module-uitkomstes van $W K V 172$ en is ook so gestel om die skakel tussen ander leerkontekste eksplisiet uit te lig. Die hooffokus van die vraelys is om inligting by studente in te win oor die gebruik van hul lees- en denkstrategieë vir hul algemene leerwerk ten einde genuanseerde afleidings te kan maak oor die sukses van onderrig in die oordraagbaarheid van vaardighede tussen gelyksoortige sowel as ongelyksoortige leerkontekste onder optimale omstandighede.

Die vraelys bestaan uit drie afdelings en 21 vrae wat breedweg soos volg beskryf kan word: Die eerste afdeling het dit ten doel om die respondente se demografiese profiel saam te stel. Hiernaas moes die student 'n aantal vrae beantwoord wat oor die rol van lees en skryf in hul studies handel. Die doel van hierdie stel vrae is om te bepaal met watter soort akademiese lees- en skryftake hulle te make het, die voorbereidingsvlak verbonde aan hierdie take en die soort steun wat die Universiteit in hierdie opsig moet bied. Die derde afdeling handel oor die soort oordrag en die vlak van oordrag wat deur taalondersteuningskursusse na inhoudsgebaseerde kursusse plaasvind. Studente moes hul lees- en skryfvermoëns op 'n Likertskaal (soos uiteengesit en verduidelik deur Carifio \& Perla, 2007) van 1 tot 5 beoordeel $(1=$ verskil sterk; $5=$ stem volkome saam) en by sommige vrae moes studente ook meer reflektief te werk gaan en oop vrae voltooi. Hierdie artikel fokus slegs op daardie vrae waar studente kwalitatiewe terugvoer moes gee aangesien hierdie tipe terugvoer veranderlikes, wat moeilik kwantifiseerbaar en waaraan die navorser moontlik nie gedink het nie is, kan uitwys sodat betekenisvolle afleidings en dus moontlike gevolgtrekkings gemaak kan word. Die kwalitatiewe terugvoer wat uit die oop vrae verkry is, het dit moontlik gemaak om die kompleksiteite van vaardigheidsoordrag beter te verstaan, aangesien verhoudings en veral patrone geïdentifiseer kon word ten einde die multidimensionaliteit van vaardigheidsoordrag bloot te lê. Die verkreë data uit die oop vrae is ook waardevol omdat die respondente weet dat hulle opinies vir die navorsers geloofwaardig is en gevolglik na waarde geskat word (Millhiser, 2008).

\section{BESKRYWING VAN EN AFLEIDING UIT VRAE}

Of die respondente tevrede is met die wyse waarop oordrag van lees- en leervaardighede deur die hoofpadmodel plaasgevind het, is spesifiek aan die vraelys getoets deur die vraag: 'Hoe dink jy dra die kursus waarvoor jy hierdie vraelys moes invul tot jou doeltreffende lees, skryf 
en leer vir 'n spesifieke toets/eksamen by?' Hierdie vraag is voorafgegaan deur aaneenskakelende vrae soos: 'Wanneer jy vir 'n toets, bv. 'n Biologie-toets, voorberei, leer jy al die inhoud of kies jy dele van die teks om te leer?' en 'Hoe suksesvol dink jy is jou strategie vir studiedoeleindes?' Respondente moes of 'n veelkeusevraag beantwoord of 'n motivering skryf.

Die 2009-kohort het uit 'n totaal van 695 studente bestaan waarvan 358 studente die module in Afrikaans gevolg het en 337 in Engels. Uit die 695 studente het 46,3\% die elektroniese vraelys voltooi, waarvan 190 respondente Afrikaans en 132 Engels was. Die respondente van beide taalgroepe het oorwegend positiewe kommentaar (60\%) gelewer, terwyl slegs $17 \%$ van die kommentaar suiwer negatief was. As daar afsonderlik na die twee taalgroepe se terugvoer gekyk word, het die Afrikaanse respondente soos volg gereageer:108 het suiwer positiewe kommentaar gelewer, 39 suiwer negatiewe kommentaar, 19 positiewe sowel as negatiewe kommentaar, en 24 respondente het geensins geantwoord nie. Hierteenoor het 85 van die Engelse respondente suiwer positiewe kommentaar gelewer, 16 suiwer negatiewe kommentaar, 9 positiewe sowel as negatiewe kommentaar, en 22 respondente het verkies om nie die vraag te beantwoord nie.

\section{DATA-ANALISE}

Wat die positiewe kommentaar betref, het 185 respondente waarde aan die komponente van die begripslees- en kritiesleestegnieke geheg, byvoorbeeld teksanalise, opsomming en argumentering. Daar was selfs 10 studente wat vir 'n eerste maal formeel in hierdie vaardighede onderrig is. Van dié kategorie studente was ook $80 \%$ van mening dat die module hulle gehelp het om groot volumes leeswerk te hanteer. Die kritiesleestegniek het hulle daartoe in staat gestel om tekste vanuit 'n ander invalshoek te lees deur hul eie afleidings te kan maak en om dus nie net alles in gelese tekste klakkeloos te aanvaar nie. Verder het 20 studente besef dat die onderrig van kritiese denkvaardighede nie slegs in hul eerstejaar 'n kardinale rol speel nie, maar dat dit ook denkvaardighede is wat hulle na latere studiejare en na die wêreld daar buite kan saamdra om uiteindelik 'n beter bydrae tot die samelewing te kan maak. Strategieë waarmee hulle in die leesmodule toegerus is was behulpsaam om die skryfproses meer strategies aan te pak. Positiewe kommentaar is ook deur 96 studente gelewer op die verbetering van hul lees- en skryfvaardighede tot op 'n wetenskaplike vlak. Die manifestering van hierdie positiewe kommentaar was ook duidelik merkbaar in die gehalte van die studente se skryfwerk aan die einde van die kursus waartydens hulle aan tekste met 'n meer komplekse argumentstruktuur en woordeskat blootgestel was en waarop hulle ook genuanseerde reaksies moes formuleer.

Ander aspekte van die kursus waarop 39 studente positief gereageer het, was die kleingroepbenadering waarin die kursus onderrig is. Bykans elke klas het uit 'n maksimum van 45 studente bestaan. Die feit dat studente hul groot skryf- en leesopdragte in groepe kon aanpak het gevolglik meer tyd vir substansiële kommentaar en intervensie deur die dosent toegelaat. Hierbenewens het 46 studente die lewendige klasbesprekings onderhoudend gevind. Dieselfde studente het selfs aangedring op meer debatvoering aangesien dit vaardighede is wat ook in ander kontekste noodsaaklik is. 'n Groep van 70 respondente het die inhoud van die kursus relevant en interessant gevind en kon die direkte skakel met 'n ander eerstejaarsmodule (Biologie 124) insien. 
Wat die negatiewe kommentaar betref, het 55 studente heftig reageer teenoor die wanbalans tussen die kursusinhoud en vak se aantal krediete. Hierdie groep het gevoel dat hulle meer tyd aan ander vakke sou wou spandeer. Dié negatiewe response was waarskynlik afkomstig van studente wat meer syfermatige vakke neem. Ander negatiewe kommentaar van 13 respondente is gelewer op die vanselfsprekendheid van die onderrigde vaardighede. Hierdie studente was van mening dat studente nie sonder akademiese lees- en skryfvaardighede tot 'n universiteit sou toegelaat word nie en dat sulke vaardighede nie aanleerbaar is nie. Dié tipe terugvoer getuig waarskynklik weer van studente se beperkte kulturele en waardeskemata en gebrekkige kritiese denke oor die demografie van Suid-Afrika. 'n Laaste noemenswaardige punt is dat 12 studente die 'nutteloosheid' van die kursus daaraan toegeskryf het dat hulle tevrede met hul eie studiestrategie is. Hier het studente dus glad nie daarin geslaag om hul eie opmerksaamheid te ontwikkel nie.

\section{GEVOLGTREKKING}

Uit hierdie ondersoek het dit geblyk dat die nuttigheid en volhoubaarheid van 'n akademiese intervensie om studente te ondersteun deur hulle met akademiese leesstrategieë en vaardighede vir ander leerkontekste toe te rus wel uit hierdie ondersoek kan afgelei word. Die kwalitatiewe terugvoer van die respondente getuig daarvan dat die persepsie by studente bestaan dat oordrag wel plaasgevind het waar sekere optimale omstandighede vir oordrag geskep is. Verskeie redes kan hiervoor aangevoer word:

Die toepassing van onder meer 'n leerdergesentreerde benadering en probleemgebaseerde onderrig het tot gevolg dat studente hulle eie leerwerklikheid konstrueer waarvoor daar in die klaskamer ruimte geskep word deur die dosent as fasiliteerder. Deur middel van die onderrig van lees- en denkvaardighede en 'n reflektiewe benadering daaroor, kon studente wel sien hoe hulle dit met gelyksoortige en ook soms ongelyksoortige vakinhoude kon versoen.

Afgesien van die onderrigbenadering moet die rol van die dosent as fasiliteerder nie onderskat word nie. Deur die dosent is die rol van vaardigheidsoordrag in die onderwysomgewing gekonkretiseer met die skep van optimale omstandighede vir vaardigheidsoordrag. Studente het genoegsame geleentheid gehad vir die deeglike en diverse inoefening van tegnieke, strategieë en vaardighede. Verder is studente deurlopend met behulp van eksplisiete abstrahering en die gebruik van metafore en/of analogieë, waar van toepassing, gewys hoe leesstrategieë suksesvol van een vakverwante en ook andersoortige probleemoplossingsituasie na 'n ander oorgedra kan word. Ook het die dosent studente aangemoedig om deur middel van aktiewe selfmonitering én die stimulering van opmerksaamheid onafhanklike, verantwoordelike leerders te word. Studente kon aktief betrokke raak by die verwerwing van lees- en denkvaardighede en die toepassing daarvan in verskillende kontekste, terwyl hulle terselfdertyd kennis rakende die inhoud van die leestake kon bemeester.

Om meer en beter vaardigheidsoordrag te verseker sou dit die ideaal wees dat die kursusperiodes van tans slegs twee periodes per week vermeerder kon word om die grondpadbenadering meer uitgebreid te kon toepas. Dit sou studente groter insig in en waardering vir die relevansie van die kursus in verhouding tot hul ander vakke kon bied. Dosente sou hulle ook beter in die beginsels van vaardigheidsoordrag kon onderlê. 


\section{SLOTOPMERKING}

Op hierdie punt wil die skrywers dit duidelik stel dat die studie wel onderwerp is aan etlike beperkings: die inligting word as 'n selfgerapporteerde studie aangebied wat sekere kritiese vrae oor die geldigheid van die bevindings mag uitlok. Verder is faktore wat studente se persepsies oor vaardigheidsoordrag kon beïnvloed, soos akademiese taalvermoë, hul kennis en begrip van die belang van die oordrag van vaardighede en respondente se verskillende persoonlikheidstipes, wat hul ontvanklikheid al dan nie bepaal oor die wyse waarop vaardighede en die oordraagbaarheid daarvan onderrig word, vir hierdie studie buite rekening gelaat. Hierbewenens is die data deskriptief, wat die veralgemening en diensooreenkomstige toepasbaarheid daarvan op ander modules bemoeilik. Nogtans blyk dit dat die kwalitatiewe data uit die elektroniese vraelys die moontlikheid van 'n positiewe indruk oor vaardigheidsoordrag binne die module ondersteun omdat dit toon dat studente wel bewus is van veral die nut en toepaslikheid van dit wat hulle in WKV 172 geleer, of verwerf, het. Kernfrases soos 'wetenskaplike denke', 'suksesvolle leer' en 'krities lees' in die respondente se terugvoer dui inderdaad daarop dat studente op 'n bewuste manier kennis en vaardighede aangeleer en verwerf het. Die kursus kan dus wel binne die konteks waarin dit tans plaasvind as 'n beginpunt vir die skepping van 'n moontlike voertuig vir suksesvolle oordrag gesien word.

\section{BRONNELYS}

BARNETT, R. 2004. Learning for an unknown future. Higher Education Research and Development, 23(3):247-260.

BARRIE, S. 2006. Understanding what we mean by the generic attributes of graduates. Higher Education, 51(2):215-241.

BELMONT, JM, EC BUTTERFIELD \& RP FERRETTI. 1982. To secure transfer of training instruct self-management skills. In Detterman, DK \& RJ Sternberg (Eds.), How and how much can intelligence be increased. Norwood, NJ: Ablex. 147-154.

BESSICK, SC. 2008. Improved critical thinking skills as a result of direct instruction and their relationship to academic achievement. Ongepubliseerde doktorale proefskrif. Indiana, PA: Indiana Universiteit van Pennsylvanië.

BILLING, D. 2007. Teaching for transfer of core/key skills in higher education: Cognitive skills. Higher Education, 53(4):483-516.

BOWDEN, J, G HART, B KING, K TRIGWELL \& O WATTS. 2000. Generic capabilities of ATN University Graduates. Canberra: Australian Government Department of Education, Training and Youth Affairs. [Intyds]. Beskikbaar: http:/www.clt.uts.edu.au/ATN.grad.cap.project.index.html

CARIFIO, J \& RJ PERLA. 2007. Ten common misunderstandings, misconceptions, persistent myths and urban legends about Likert scales and Likert response formats and their antidotes. Journal of Social Sciences 3(3):106-116.

CARTER, S \& R PITCHER. 2010. Extended metaphors for pedagogy: Using sameness and 
difference.Teaching in Higher Education, 15(5):579-589.

CHI, MTH \& KA VANLEHN. 2012. Seeing deep structure from the interactions of surface features. Educational Psychologist, 47(3):177-188.

DAY, SB \& RL GOLDSTONE. 2012. The import of knowledge export: Connecting findings and theories of transfer of learning. Educational Psychologist, 47(3):153-176.

DIAMOND, RM. 1997. Curriculum reform needed if students are to master core concepts. [Intyds]. Beskikbaar: http://chronicle.com/article/Curriculum-Reform-Needed-if/76746.

DE CORTE, E. 1999. On the road to transfer: An introduction. International Journal of Educational Research, 31:555-559.

DETTERMAN, DK. 1993. The case for the prosecution: Transfer as an epiphenomenon. In Detterman, DK. \& RJ Sternberg (Eds.), Transfer on trial: Intelligence, cognition, and instruction. Norwood, NJ: Ablex. 1-24.

FALLON, D, CJ LAHAR \& D SUSMAN. 2009. Taking the high road to transfer: Building bridges between English and Psychology. Teaching English in the Two-Year College, 37:41-55.

GICK, ML \& KJ HOLYOAK. 1980. Analogical problem solving. Cognitive Psychology, 12:306-365.

GICK, ML \& KJ HOLYOAK. 1983. Schema induction and analogical transfer. Cognitive Psychology, 15:1-38.

GLYNN, SM, RH YEANY \& BK BRITTON. 1991.(Eds.), The psychology of learning science. Hillsdale, NJ: Erlbaum.

GLYNN, SM \& T TAKAHASHI. 1998. Learning from analogy-enhanced science text. Journal of Research in Science Teaching, 35:1129-1149.

HADIYANTO. 2010. The development of core competencies at Higher Education: A suggestion model for universities in Indonesia. International Journal for Educational Studies, 3(1):11-22.

HANLEY, S. 1994. On constructivism. Ongepubliseerd. Maryland Collaborative for Teacher Preparation. [Intyds]. Beskikbaar: http://www.inform.umd.edu/UMS\%2BState/UMDProjects/MCTP/Essays/Constructivism.txt [2011, 19 Mei].

HASKELL, EH. 2001. Transfer of learning: Cognition, instruction and reasoning. New York, NY: Academic Press.

JAMES, MA. 2010. An investigation of learning transfer in English-for-general-academic purposes writing instruction. Journal of Second Language Writing, 19:183-206.

LANGER, EJ. (1989). Mindfulness. Reading, MA: Addison Wesley.

LURIA, AR. 1976. Cognitive development: Its cultural and social foundations. 
Cambridge, MA: Harvard University Press.

MARINI, A \& R GENEREUX. 1995. The challenge of teaching for transfer. In McKeough, A., J Lupart \& A Marini, A. (Eds), Teaching for Transfer: Fostering generalisation in learning. Mahwah, NJ: Lawrence Erlbaum. 1-20.

MILLHISER, W. 2008. Open ended questions in OR/MS Education. [Intyds]. Beskikbaar: blsciblogs.baruch.cuny.edu [2012, 14 November].

NAGEL, L, S BLIGNAUT \& J CRONJÉ. 2011. The surprising truth about how metaphor motivates e-learners. Ongepubliseerde referaat gelewer by Australian Society for Computers in Learning in Tertiary Education. 4-7 Desember 2011, Hobart, Tasmanië.

PERKINS, DN \& G SALOMON. 1987. Transfer and teaching thinking. In Perkins D.N, J Lochhead \& J Bishop (Eds.), Thinking: The second international conference. Hillsdale, NJ: Erlbaum. 285-303.

PERKINS, DN \& G SALOMON. 1988. Teaching for transfer. Educational Leadership, 46:22-32.

PERKINS, DN \& G SALOMON. 1992. Transfer of Learning. International Encyclopedia of Education, 2:1-13. Oxford, UK: Pergamon Press. [Intyds]. Beskikbaar: http://learnweb.harvard.edu/alps/thinking/docs/traencyn.htm

PERKINS, DN \& G SALOMON. 2012. Knowledge to go: A motivational and dispositional view of transfer. Educational Psychologist, 47(3):248-258.

RAMSDEN, P. 1988. Studying learning: Improving teaching. In Ramsden, P. (Ed.), Improving learning: New Perspectives. London, UK: Kogan Page.

RUGARCIA, A, RM FELDER, DR WOODS \& JE STICE. 2000. The future of engineering education-I: A vision for a new century. Chemical Engineering Education, 34(1):16-25.

RESNICK, LB. 1987. Learning in school and out. Educational Researcher, 16:1320.SALOMON, G. \& DN PERKINS. 1987. Transfer of cognitive skills from programming: When and how? Journal of Educational Computing Research, 3:149-169.

SALOMON, G \& T GLOBERSON. 1987. Skill may not be enough: The role of mindfulness in learning and transfer. International Journal or Educational Research, 6(11):623-637.

SALOMON, G \& DN PERKINS. 1989. Rocky roads to transfer: Rethinking mechanisms of a neglected phenomenon. Educational Psychologist, 24(2):113-142.

STUPNISKY, RH, RD RENAUD, LM DANIELS, TL HAYNES \& RP PERRY. 2008. The interrealation of first-year college students' critical thinking disposition, perceived academic control and academic achievement. Research in Higher Education, 49:513530 . 
TAALDIENS, US TAALSENTRUM. 2012. Korrespondensie. 14 November, Stellenbosch.

VAN DYK, TJ, K CILLIÉ, ML COETZEE, SLA ROSS \& H ZYBRANDS. 2011. 'n Ondersoek na die impak van'n leesintervensie op eerstejaarstudente se akademiese leesvaardigheid. [Intyds]. Beskikbaar: http://www.argief.litnet.co.za/cgibin/giga.cgi?cmd=cause_dir_news_item\&cause_id=1270\&news_id=113645\&cat_id=20 1

YAGER, R. 1991. The constructivist learning model: Towards real reform in science education. The Science Teacher, 58(6):52-57.

\section{BIOGRAFIESE NOTA}

Karlien Cillié is 'n dosent verbonde aan die Eenheid vir Afrikaans en Engels, Taalsentrum aan die Universiteit Stellenbosch. Sy doseer die afgelope 11 jaar in haar belangstellingsveld, naamlik taalontwikkelings- en verwerwingsmodules sowel as akademiese geletterdheid.

Marisca Coetzee is ' $n$ dosent verbonde aan die Eenheid vir Afrikaans en Engels, Taalsentrum aan die Universiteit Stellenbosch. Sy doseer die afgelope 10 jaar taalontwikkelings- en verwerwingsmodules sowel as akademiese geletterdheid. Haar belangstellings lê veral by akademiese geletterdheid, kenmerke van die afgestudeerde ('graduate attributes') en leerdergesentreerde onderrigbenaderings. 